\title{
Seasonal variations of major ionic concentration levels in drifting-snow samples obtained from east Dronning Maud Land, East Antarctica
}

\author{
KAZUO OSADA \\ Solar-7errestrial Environment Laboralory, Nagoya University, Nagoya 464-01, Japan
}

\begin{abstract}
ABSTR $\triangle$ CT. Drifting-snow samples were collected at Mizuho Station $\left(74^{\circ} 42^{\prime} \mathrm{S}\right.$, $44^{\circ} 20^{\prime} \mathrm{E}, 2230 \mathrm{~m}$ a.s.l. from February to October 1986 and along traverse routes in east Dronning Maud Land (1800-3000 m a.s.l.), East Antarctica, from October 1986 to January 1987. The typical sampling interval was about once a week but two sets of intensive sampling were made at the end of February and November at between $2 \mathrm{~h}$ and $1 \mathrm{~d}$ intervals.

Measurements for $\mathrm{Cl}^{-}, \mathrm{NO}_{3}, \mathrm{SO}_{4}{ }^{2}$ and $\mathrm{Na}^{+}$were made on the drifting-snow samples by ion chromatography. Oxygen-isotope ratios were also measured on the samples. Concentrations levels of $\mathrm{NO}_{3}$ and $\mathrm{SO}_{4}{ }^{2-}$ show distinctive scasonal variations: high in summer 4.6 neq $\mathrm{g}^{1}$ for $\mathrm{NO}_{3}$ and $3.3 \mathrm{neqg}{ }^{1}$ for $\mathrm{SO}_{4}{ }^{2}$ ) and low in winter during mid-March to mid-November ( 1.0 neqg ${ }^{1}$ for $\mathrm{NO}_{3}$ and 0.5 necg ${ }^{1}$ for $\mathrm{SO}_{4}{ }^{2}$ ). Results obtained at Mizuho Station show that the transition from the summer high values to winter low values takes about $20 \mathrm{~d}$ for $\mathrm{NO}_{3}$ and $\mathrm{SO}_{4}{ }^{2}$. The variations in $\mathrm{Cl}$ and $\mathrm{Na}^{+}$concentration levels are small in both autumn and spring (averages are about $1 \mathrm{neq}^{-1}$ ) with greater variability throughout the rest of the year. 'I he intensivesampling data set shows that there is considerable variability within a day with $\mathrm{NO}_{3}$ and $\mathrm{SO}_{1}{ }^{2-}$ concentration levels up to about a factor of 4 associated with a $10 \%$ change in $\delta^{18} \mathrm{O}$ ratios.
\end{abstract}

\section{INTRODUCTION}

Studies on the chemical constituents of ice cores obtained from polar ice sheets have provided information on the past atmospheric environment (see reviews: Clausen and Langway, 1989; Delmas, 1992). Seasonal variations in concentration levels of chemical constituents recorded in snow deposits and icc cores have been used to identify annual layers of snow or ice and to investigate sources of constitucnts (Hcron, 1982; Lcgrand and Delmas, 1984). Studies on fallen and drifting-snow samples are essential to understand the chemical stratigraphy of seasonal variations at the concentration levels of constituents in deposited snow. However, reports on the chemistry of fallen and drifting-snow samples are very limited for (1) the number of samples measured Maupetil and Delmas, 1992) and (2) the period of sampling (Kamiyama and others, 1989).

Even under clear-sky conditions, drifting- or blowingsnow phenomena are observed at Mizuho Station duc to strong katabatic winds. Drifting-snow particles originate from the snow surface by wind erosion. Under precipitating conditions, newly fallen snow particles are mixed with the drifting-snow particles. These mixed snow particles, as well as aged drifting-snow particles, again deposit on to the snow surface. In other words, deposited snow in a katabatic-wind region consists of a mixture of newly fallen and aged drifting-snow particles. Since such settled snow is called "snowdrift", in the same manner, snow trapped in a sampling bottle in a small pit is defined as "snowdrift trapped" in this paper.

The purpose of this study is to extend the preliminary chemical data (Osada and others, 1989) of trapped snowdrift samples obtained from east Dronning Maud Land, East Antarctica, and to investigate the detailed seasonal and short-term (time-scale of a few hours to a day variation of major soluble constituents $\left(\mathrm{Cl}, \mathrm{NO}_{3}\right.$. $\mathrm{SO}_{4}{ }^{2-}, \mathrm{Na}^{+}$) of the trapped snowdrift samples.

\section{SAMPLING AND ANALYSIS}

Samples of drifting snow were taken at Mi uho Station (70'42' S, 44 $20^{\prime} \mathrm{E}, 2230 \mathrm{~m}$ a.s.l.) from Fcbruary to Scptember 1986, and along oversnow traverse roules in east Dronning Maud Land (1800-3000 ma.s.l.) from October 1986 to January 1987. Figure 1 is a location map of Mizuho Station and the traverse routes. In Figure 1, thick lines indicate the traverse routes where snow-trap sampling was made. The observed area in this study is categorized as a cold katabatic region (Dalrymple, 1966), where drifing and blowing snow conditions are frequently observed see details for drifting-snow conditions at Mizuho Station in Kobayashi (1978) and Takahashi (1985)).

Snow-trap sampling was carried out with special care to avoid contamination from snow vehicles, station and 


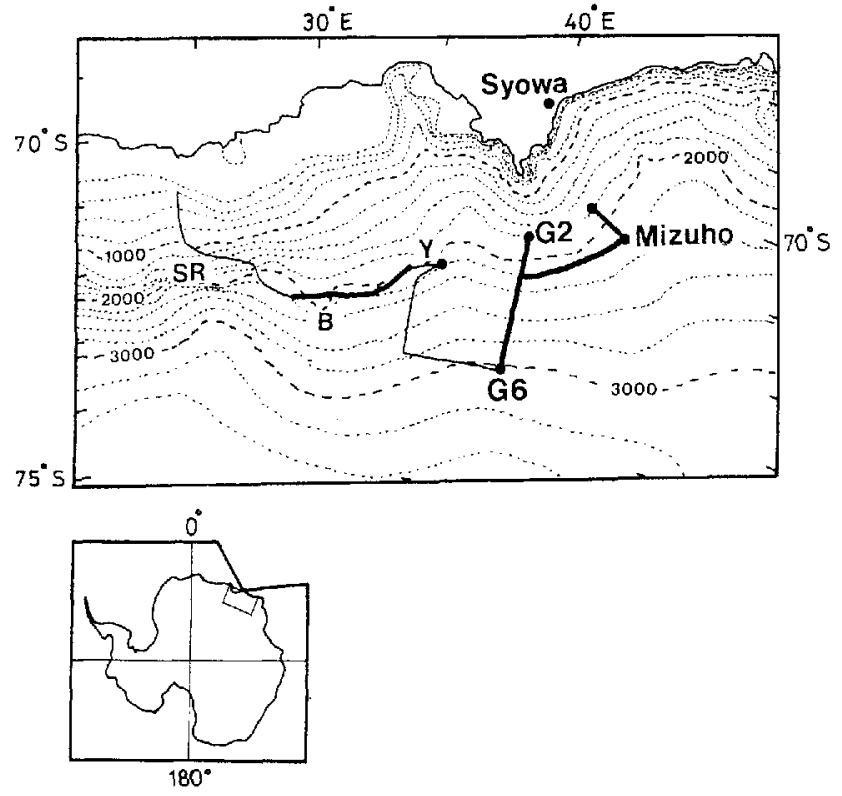

Fig. 1. Map of traverse routes in east Dronning Maud Land, Antarclica. Trap sampling of drifting snow was conducted along the routes shown by the thick lines. 62 and G6: glaciological obsenation sites, Y: Yamato Mounlains, B. Belgicafjella and SR: Sor-Rondane mounlains.

human activities, wearing clean clothing, clean mask and powder-fiee clean PVC gloves. Since the direction of katabatic winds is stable at a given location, all sampling pits were set in a position at least $100 \mathrm{~m}$ upwind of station and field-camp activities. Sampling personnel were always kept in their position downwind of the prevailing katabatic wind direction against the sampling bottles and equipment.

Polypropylcne (PP) sampling bottles (11) were preclcaned as reported by Kanamori and others (1987). About 100-300 g of snow sample drifting just above the snow surface was directly trapped into the wide-mouth 11 PP bottle. The weight of trapped snow depends on type of drifting-snow particles: a lighter weight for mixed drifting snow with newly fallen snow particles and a heavier weight for aged drifting-snow particles. The sampling duration is typically between $1 \mathrm{~h}$ and a few hours until a full sampling-bottle set was obtained in a small pit which is as deep as the height of the bottle (Osada and others, 1989). Then they were sealed in double PE bags and kept frozen until analysis in the laboratory in Japan.

Polyethylene (PE) sampling bottles $(250 \mathrm{ml})$ were precleaned only by deionized water without the use of acids. Some duplicate snow samples using both the PP and the PE bottles were made for comparison of bottle-cleaning procedures.

As described in a previous paper (Osada and others, 1989), snow samples were melted at room tempcrature in the laboratory and immediately filtered through a membrane filter Nuclepore filter with a $0.22 \mu \mathrm{m}$ pore size). In this study, concentrations of $\mathrm{Na}^{+}, \mathrm{Cl}, \mathrm{NO}_{3}$ and $\mathrm{SO}_{4}{ }^{2-}$ in non-filtered meltwater samples from both the 11 $\mathrm{PP}$ and the $250 \mathrm{ml} \mathrm{PE}$ bottles were measured by an ion chromatograph (Dionex 2000i/SP) in the laboratory of the National Institute of Polar Research in Tokyo. Comparison of duplicatc samples for bottle-cleaning procedures and filtered/non-filtered samples show an insignificant difference for ions measured, within an error of ionchromatographic measurements (typically $<10 \%$ ).

Table 1. Concentration levels of major ionic constituents in snowdrift

$\mathrm{NO}_{3} \mathrm{SO}_{4}{ }^{2-} \quad \mathrm{Cl}^{-}$
$\mathrm{neqg}^{-1}$

Summer: $26 \mathrm{Jan} 17 \mathrm{Mar}$ and $13 \mathrm{Xoz}-18 \mathrm{Jan}$ (49 samples)

\begin{tabular}{|c|c|c|c|c|c|c|}
\hline Average & 4.63 & 3.29 & 1.94 & 1.48 & 3.10 & 0.25 \\
\hline STD & 2.37 & 2.46 & 1.32 & 1.91 & 2.35 & 1.55 \\
\hline Minimum & 1.69 & 0.50 & 0.31 & 0.09 & 0.25 & -8.28 \\
\hline Maximum & 11.66 & 11.28 & 8.99 & 9.52 & 10.14 & 2.85 \\
\hline
\end{tabular}

IIinter: 18 Mar-12 Nov (55 samples)

\begin{tabular}{|c|c|c|c|c|c|c|}
\hline Average & 0.97 & $0 . \tilde{5} 0$ & 1.72 & 1.13 & 0.37 & 0.39 \\
\hline STD & 0.40 & 0.19 & 1.38 & 0.96 & 0.19 & 0.39 \\
\hline Minimum & 0.21 & 0.17 & 0.17 & 0.04 & -0.12 & 0.37 \\
\hline Maximum & 2.15 & 0.94 & 7.46 & 4.39 & 0.81 & 2.34 \\
\hline
\end{tabular}

Lear 1986: 26 Jan 1986-18.Jan 1987 (104 samples)

\begin{tabular}{|c|c|c|c|c|c|c|}
\hline Arcrage & 2.69 & 1.81 & 1.83 & 1.30 & 1.66 & 0.37 \\
\hline STD & 2.47 & 2.19 & 1.35 & 1.52 & 2.12 & 1.13 \\
\hline Minimum & 0.21 & 0.17 & 0.17 & 0.04 & -0.12 & 8.28 \\
\hline Maximum & 11.66 & 11.28 & 8.99 & 9.52 & 10.14 & 2.85 \\
\hline
\end{tabular}

STD, Standard deviation. 
The isotopic composition of the meltwater was obtained by analyses with a MAT 250 mass spectrometer at the Water Research Institute, Nagoya, on $\mathrm{CO}_{2}$ equilibrated with the meltwater of the samples. The analytical error was less than $0.2 \%$ in $\delta^{18} \mathrm{O}$.

\section{RESULTS AND DISCUSSION}

Figure 2 shows the variation of $\delta^{18} \mathrm{O}$ values measured on the snowdrift samples trapped and the elevation of the sampling points. Variation of the $\delta^{18} \mathrm{O}$ values includes short-term variations during a precipitation event (sampled at Mizuho Station until carly October) and changes in the sampling-site elevation as well as distance from the coast. Temporal and spatial variations in the $\delta^{18} \mathrm{O}$ values for this region have been described by Watanabe and others $(1981,1988)$ and Ageta (1993).

Figure 3 shows results of chemical analyses of the snowdrift samples that were trapped. In Figure 3, triangles represent snow samples containing newly fallen snow and open circles represent drifting-snow samples without falling snow. No samples were obtained for the
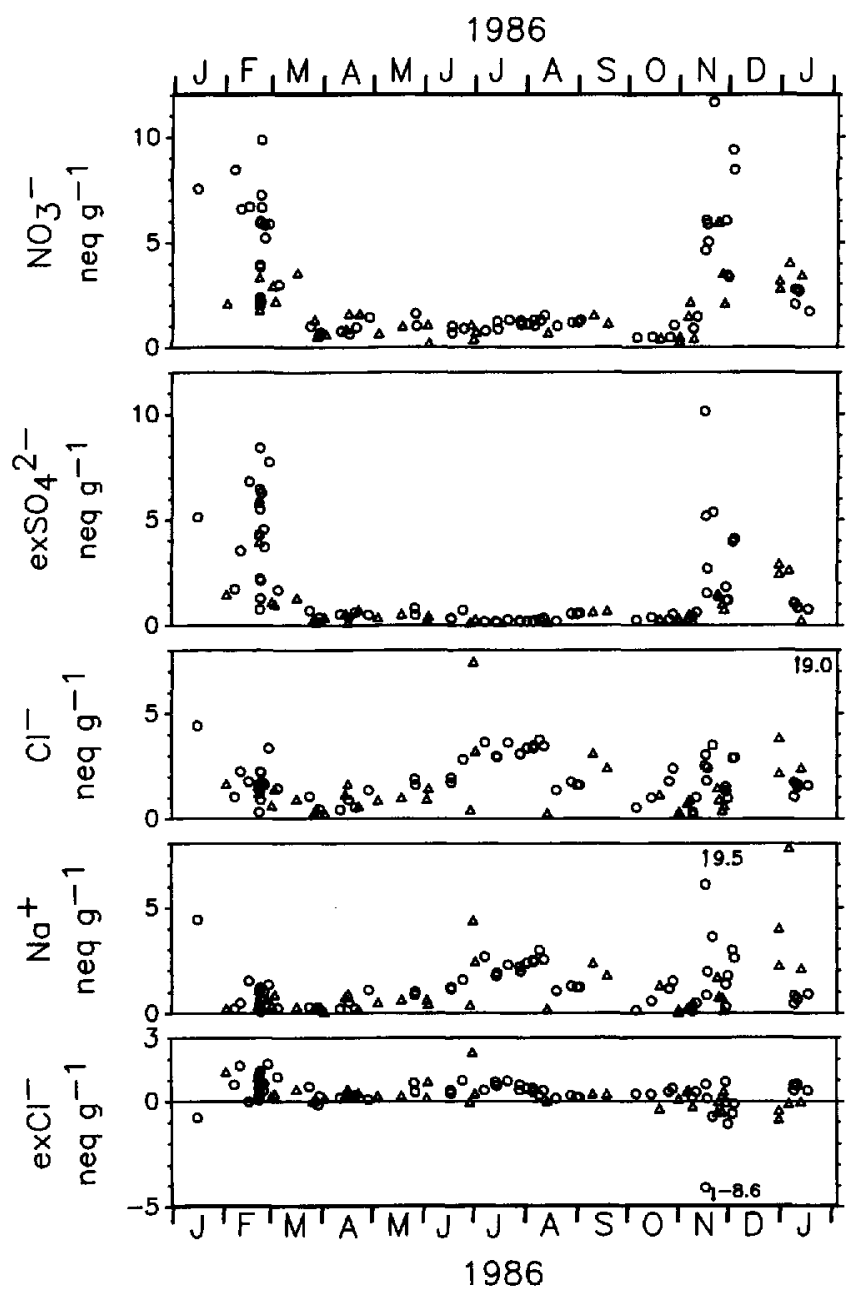

Fig. 3. Variations in concentration levels of ionic constituenls in trapped snowdrift samples obtained from east Dronning Maud Land. Triangles represent snow! samples conlaining fresh falling-snow particles. Open circles represent snow samples without falling-snow particles.
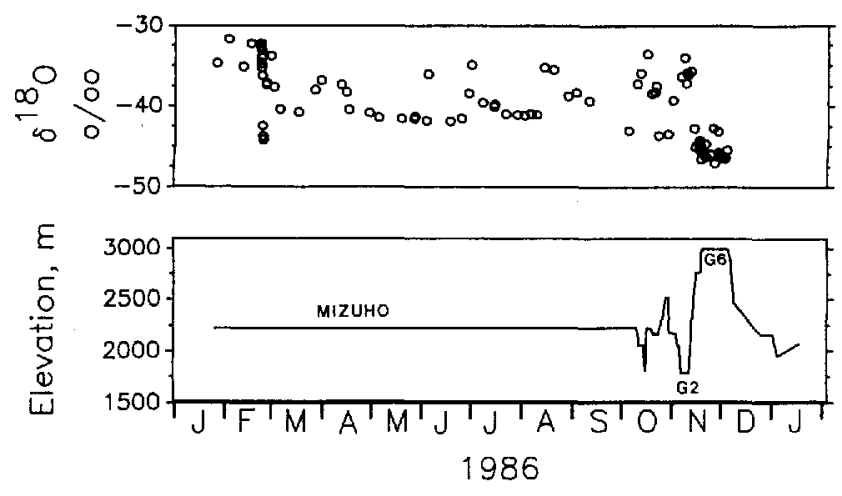

Fig. 2. Oxygen-isotope ratio of drifling-snow samples trapped (upper) and elevation (ma.s.l.) of sampling points (lower). Station names of longer duration of stay are indicated for Mizuho Stalion, $G 2$ and $G 6$ sites.

gaps in December in the figure, because of the traverse of the bare icefield in the Yamato Mountains arca. The results are summarized in Table 1. Excess $\mathrm{SO}_{4}{ }^{2-}$ concentrations (abbreviated as exSO ${ }_{4}{ }^{2-}$ hereafter) are the non-sea-salt part of the total $\mathrm{SO}_{4}{ }^{2-}$ content measured. The exSO ${ }_{4}{ }^{2}$ concentrations are calculated from the measured $\mathrm{SO}_{4}{ }^{2-}$ and $\mathrm{Na}^{+}$contents of the samples using the $\mathrm{SO}_{4}{ }^{2-}$, $\mathrm{Na}^{+}$ratio in sea water $(0.12$ in equivalent units).

The seasonal variations in the concentrations of $\mathrm{NO}_{3}$ and $\mathrm{exSO}_{4}{ }^{2-}$ in the snowdrift trapped show distinctive maxima in summer and minima in winter. Concentration levels for $\mathrm{NO}_{3}{ }^{-}$and exSO ${ }_{4}{ }^{2-}$ show low variabilities in winter relative to variations in summer. The amplitudes of the concentration levels between summer and winter averages (Table 1) are 4.8 times for $\mathrm{NO}_{3}^{-}$(summer, $4.63 \sim$ winter, 0.97 neq $^{1}$ ) and 8.4 times for $\operatorname{exSO}_{4}{ }^{2}$ (summer. $3.10 \sim$ winter, $0.37 \mathrm{neq} \mathrm{g}^{-1}$ ). These seasonal amplitudes are close to the results of atmospheric aerosols collected at Mawson (Savoie and others, 1992): about 5 limes (summer maximum: October-1)ecember; winter minimum: AprilMay) for $\mathrm{NO}_{3}^{-}$and about 7.6 times (maximum: OctoberMarch; minimum: April-September) for $\mathrm{exSO}_{4}{ }^{2-}$.

On the other hand, detailed scasonal variations for $\mathrm{NO}_{3}{ }^{-}$and $\mathrm{exSO}_{4}{ }^{2-}$ are different from those of aerosol data collected at the coastal stations (at Georg von Neumayer: Wagenbach and others, 1988; at Mawson: Savoie and others, 1992); (1) a small winter peak of $\mathrm{NO}_{3}{ }^{-}$ concentration in aerosols does not appear in the snowdrift trapped, (2) a sharp transition from summer to winter of $\mathrm{exSO}_{4}{ }^{2}$ in the snowdrift took only about $20 \mathrm{~d}$ instead of a sinusoidal smooth curve for the results of the aerosols.

The seasonal variations in the $\mathrm{Na}^{+}$and $\mathrm{Cl}^{-}$ concentrations show a similar trend except for a few points of significant excess or a depleted amount for the $\mathrm{Cl}^{-}$concentration levels (Fig. 3). Excess $\mathrm{Cl}^{-}$concentration levels $\left(\mathrm{exCl}^{-}\right)$with respect to the sea-water composition are calculated from the $\mathrm{Cl}$ and $\mathrm{Na}^{+}$contents of the samples using the $\mathrm{Cl}^{-} / \mathrm{Na}^{+}$ratio in sea water $(1.17$ in equivalent units). The seasonal variation of $\mathrm{exCl}^{-}$is not significant but it shows excess values about $0.4 \mathrm{neq} \mathrm{g}^{-1}$ for most of the year, except for some summer depletion points. Because sampling locations were moved from Mizuho Station after early October to the inland plateau, 
the exCl profile includes changes in fractionation conditions such as the transport distance of sea salts from the coast.

Legrand and Delmas $(1985,1988)$ reported that the $\mathrm{Cl} / \mathrm{Na}$ ratio in deposited snow increases with distance inland from the coast. They suggested HCl-formation processes as follows: $\mathrm{HCl}$ is formed in the coastal area where sea-salt particles are abundant and then subsequently $\mathrm{HCl}$ is transported inland and deposited on the Antarctic Plateau. As opposed to the geographical variation of $\mathrm{Cl} / \mathrm{Na}$ in deposited snow in Terre Adélie (Legrand and Delmas, 1985), the exCl- profile in this study shows negative values with a high sea-salt concentration at the most distant location (G6) from the coast.

Figure 4 shows the short-term variations of $\delta^{18} \mathrm{O}$ and major ionic constituents measured on the snowdrift samples trapped at Mizuho Station in February 1986. The beginning of the intensive sampling set corresponds to a snow-precipitation event. This fallcn-snow condition (triangles in Figure 4) continued until the late afternoon of 22 February (Ohmae and others, 1987). The $\delta^{18} \mathrm{O}$ profile shows a decreasing trend (about 10-12\% decrease) associated with a cooling trend in the air
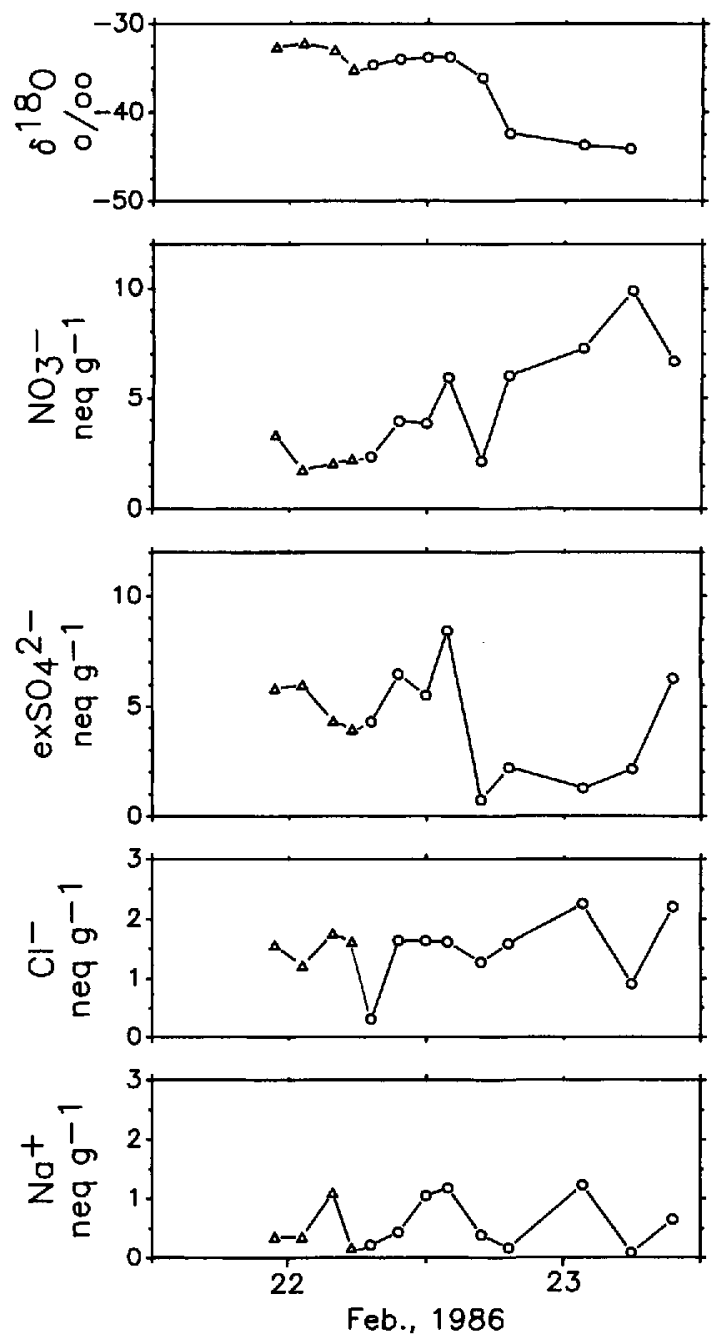

Fig. 4. Short-term variations of oxygen-isolope ratio and ionic concentration levels in snowdrift samples trapped at Mizuho Station. Triangles and circles represent the same as in Figure 3. temperature (about $7^{\circ} \mathrm{C}$ decrease) within a day. After precipitation stopped, concentration levels of $\mathrm{NO}_{3}$ showed an increasing trend but exSO ${ }_{4}{ }^{2-}$ increased until after noon then decreased at once. The sea-salt components $\left(\mathrm{Cl}^{-}\right.$and $\left.\mathrm{Na}^{+}\right)$show a similar trend to each other but show different trends with $\mathrm{NO}_{3}{ }^{-}$and $\operatorname{exSO}_{4}{ }^{2-}$. An excess amount of $\mathrm{Cl}$ (not shown in Figure 4) always exists during this period $\left(0.06-1.43 \mathrm{neq}^{-1}\right)$. Synoptic meteorological charts during this period indicate that a cyclone passed off the coast from 21 to 22 February, then subsequently, a ridge of high pressure came over this region on 23 February.

Figure 5 shows another set of an intensive sampling period of a $16 \mathrm{~d}$ stay from 21 November to 5 December 1986 at a glaciological strain-grid station: G6 (73 $07^{\prime} \mathrm{S}$, $39^{\circ} 46^{\prime} \mathrm{E}, 3005 \mathrm{~m}$ a.s.l.; Nishio and others, 1986). During this period, intermittent precipitation events were observed from 24 to 28 November (Nishio and others, 1988). Cloudy sky conditions extended from 28 to 30 November and clear-sky conditions persisted for the rest of the period. No significant trend in the $\delta^{18} \mathrm{O}$ profile is scen in the figure, whereas major ionic contents measured show parallel trends in their variations: low concentration levels during intermittent precipitation events and cloudy
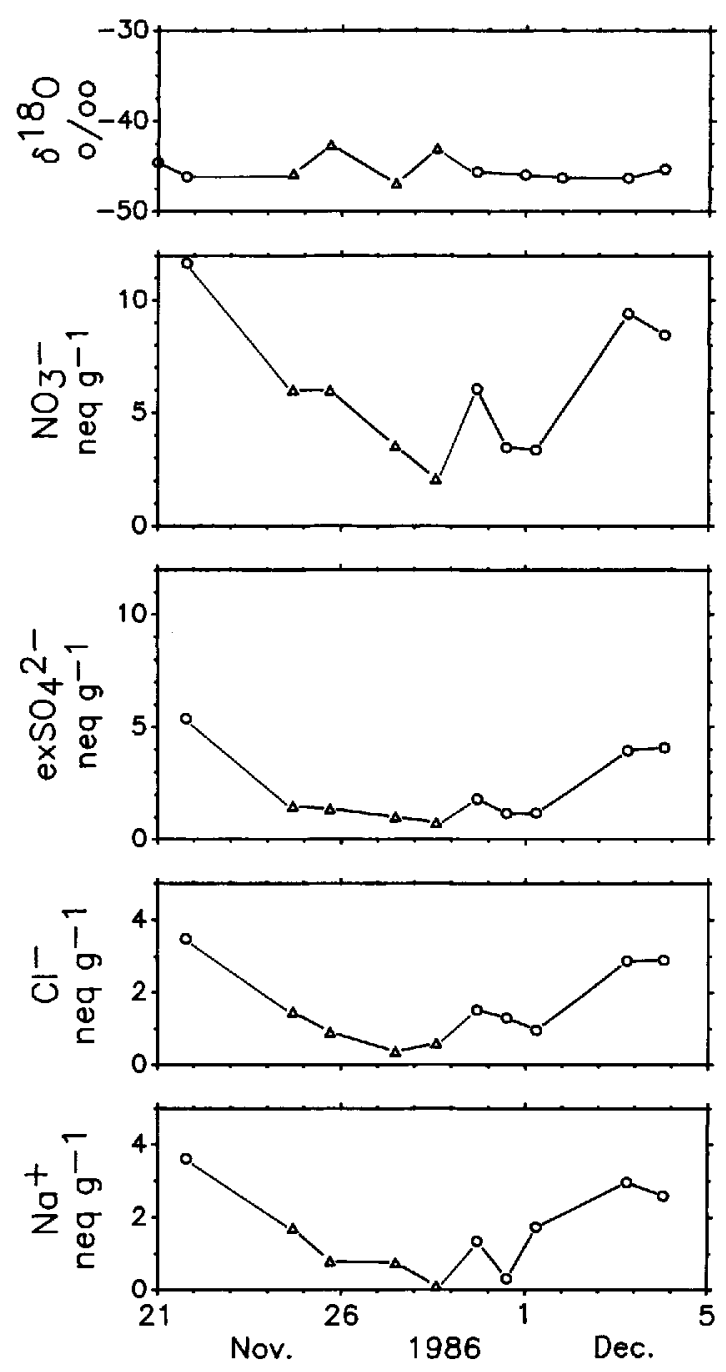

Fig. 5. Same as Figure 4 but collected at $G 6$ glaciological strain-grid station. Triangles and circles represent the same as in Figure 3. 
days. Synoptic metcorological charts do not show a passing significant ridge of high pressure over this region before or after the precipitation events.

\section{CONGLUDING REMARKS}

Despite moving sample locations from Mizuho Station after October, this study shows distinctive seasonal variations for $\mathrm{NO}_{3}{ }^{-}$and excess $\mathrm{SO}_{4}{ }^{2-}$ in drifting-snow samples trapped over east Dronning Maud Land. General trends and seasonal amplitudes of $\mathrm{NO}_{3}{ }^{-}$and excess $\mathrm{SO}_{4}{ }^{2-}$ are similar to those of reported aerosol studics made at other Antarctic stations near the coast. Details of seasonal variations in $\mathrm{NO}_{3}{ }^{-}$and excess $\mathrm{SO}_{4}{ }^{2}$ concentrations are different from those found in aerosols at the coastal stations: no small peak in winter for $\mathrm{NO}_{3}{ }^{-}$ and a sharp seasonal transition from summer to winter for excess $\mathrm{SO}_{4}{ }^{2-}$ in this study. The reason for the differences remains unexplained but the differences might have resulted from differences in transport processes of atmospheric aerosols and perhaps acidic gases at different regions, and rapid aerosol scavenging by drifting snow.

Short-term (at a time-scale of a few hours to $1 \mathrm{~d}$ ) variations of ionic concentration levels in the driftingsnow samples trapped have also been studied for the summer scason. The results show high variability, especially for $\mathrm{NO}_{3}$ and excess $\mathrm{SO}_{4}{ }^{2-}$ within the short-term periods studicd. Sampling strategy of drifting and falling snow particles, as well as atmospheric aerosols, needs 10 consider these significant short-term variations.

\section{ACKNOWLEDGEMENTS}

The author wishes to thank Drs F. Nishio and H. Ohmae, members of the 27th Japanese Antarctic Research Expedition (JARE) for helping with sample collections and meteorological observations, and Ms E. Isa, Ms E. Suzuki and Mrs T. Kobayashi for their assistance in analytical work. The author is grateful to Drs $O$. Watanabe, Y. Fujii, Y. Ageta, T. Ohata, S. Kanamori and $\mathrm{N}$. Kanamori for many useful suggestions during this work.

\section{REFERENCES}

Ageta, Y. 1993. Annual variation of oxygen isotopic contents of drifting now and the isotopic contents of deposited snow layers at Mizuho Station, Antarctica. Antart. Rer, 37, 24-31.
Clausen, H. B, and C.C. I angway, Jr. 1989. The ionic deposits in polar ice cores. In Oeschger, $\mathrm{H}$. and $\mathrm{C}$. C. Langway, Jr, eds. The environmental record in glaciers and ice sheets. New York, John Wiley and Sons, 22.5-247.

1)alrymple, P. 1966. A physical climatology of the Antarctic Plateau. In Rubin. M.J., ed. Studies in Antartic meteorology. Washington. DC. American Geophysical Union, 195-231. Antaretic Rescarch Series 9.)

Delmas, R.J. 1992. Environmental information from ice cores. Rer. Geophys., 30, 1-21.

Herron, M. M. 1982. Glaciochemical dating tcchniques. In Gurrie, L... ed. Suclear and chemical dating tadiniques: interpreting the entironmental record. ACS Symp. Ser., Vol. 176, 303 318. Washington DC, American Chemical Socicty.

Kamiyama, K., Y. Ageta and Y. Fujii. 1989. Atmospheric and depositional environments traced from unique chemical compositions of the snow over an inland high plateau, Antarctica. 7. Geophrs. Res., 94(D15;, 18,515-18,519.

Kanamori, S. and 6 others. 1987. Preliminary report on the contamination control for chemical analyses of Antarctic ice samples. Proc. IIPR Symp. Polar Meteorol. Glaciol. 1, 132-139. 'Tokyo, National Institute of Polar Research.

Kobayashi, S. 1978. Snow transport by katabatic winds in Mizuho Camp area, East Antarctica. J. Meteorol. Soc. Japan, 56, 130-139.

Legrand, M. R. and R.J. Delmas. 1984. The ionic balance of Antarctic snow: a 10-year detailed record. Atmos. Eniron, 18, $1867-1874$.

Legrand, M. and R. J. Delmas. 1985. Spatial and temporal variations of snow chemistry in Terre Adelic (East Antarctica). Am. Glaribl., 7. $20-25$.

Legrand, M. and R.J. Delmas. 1988. Formation of HCl in the Antarctic atmosphere. 7. Geophy. Res., 93 D6), 71537168.

Maupetit, F. and R. J. Delmas. 1992. Chemical romposition of falling snow at Dumont D'Lrville, Antarctica. 7. Amos. Chem., 14, 31 42.

Nishio, F., H. Ohmae and M. Ishikawa. 1986. Glaciological rescarch program in cast Queen Maud Iand, Fast Antarctica, Part 3, 1982. JARE Data Rep., 110 (Glaciology 12 ).

Nishio, F., H. Ohmac, and K. Osada. 1988. Glaciological rescarch program in cast Quecn Maud Land, Fast Antaretica, Part 7, 1986. JARE Data Ret. 137 (Glaciology 16).

Ohmae, H., K. Osada and F. Nishio. 1987. Mctcorological data at Mizuho Station, Antarctica in 1986. JARE Data Rep. 130 (Meterolog: 20 ).

Osadia, K., H. Ohmae, F. Nishio, K. Higuchi and S. Kinlamori. 1989. Chemical composition of snow drift on Mizuho Plateau. Proc. MPR Symp. Polar Metenrol. Glacinl. 2, 70-78. l'okyo, National Institute of Poliar Research.

Savoie, D. L., J.M. Prospero, R.J. Larsen and E.S. Saltzman. 1992. Nitrogen and sulfur specics in aerosols at Masson, Antarctica, and their relationship to natural radionuclides. 7. Amos. Chem., 14, 181-204.

'Takahashi, S. 1985. Characteristics of drifting snow at Mizuho Station. Antarctica. Ann. Glaciol., 6, 7175.

Wagenbach, D., L'. Gorlach, K. Moser and K. O. Munnich. 1988. Coastal Antarctic aerosol: the seasonal pattern of its chemical composition and radionuclide content. Tellus, 40B, 426436.

Watanabe, O., K. Kato and K. Satow. 1981. Some results on oxyen isotope and stratigraphic analyses of firn in Mizuho Platcau, East Antitrcica. Mem. Vall. Inst. Polar Res. Spec. Issue. 19, 264-279.

Watanabe, O., Y. Fujii and K. Satow. 1988. Depositional regime of the katabatic slope from Mizuhn Platcau to the coast, Fast Antarctica. Anm. Glaciul, 10, 188-192.

The accuracy of references in the text and in this list is the responsibility of the author, to whom queries should be addressed. 